\title{
Twinflower (Linnaea borealis L.) - plant species of potential medicinal properties
}

\author{
BARBARA THIEM ${ }^{1 *}$ ELISABETH BUK-BERGE ${ }^{2}$
}

\author{
${ }^{1}$ Department of Pharmaceutical Botany and Plant Biotechnology \\ Poznań University of Medical Sciences \\ Św. Marii Magdaleny 14 \\ 61-861 Poznań, Poland \\ ${ }^{2}$ The Norwegian Ministry of Education and Research** \\ Postbox 8119 \\ Dep. 0032 Oslo, Norway \\ *corresponding author: phone: +4861 6687851, e-mail: bthiem@ump.edu.pl
}

\section{Summary}

Twinflower (Linnaea borealis L.) is a widespread circumboreal plant species belonging to Linnaeaceae family (previously Caprifoliaceae). L. borealis commonly grows in taiga and tundra. In some countries in Europe, including Poland, twinflower is protected as a glacial relict. Chemical composition of this species is not well known, however in folk medicine of Scandinavian countries, L. borealis has a long tradition as a cure for skin diseases and rheumatism. It is suggested that twinflower has potential medicinal properties. The new study on lead secondary metabolites responsible for biological activity are necessary. This short review summarizes very sparse knowledge on twinflower: its biology, distribution, conservation status, chemical constituents, and describes the role of this plant in folk tradition of Scandinavian countries.

Key words: Linnaea borealis, botanical description, distribution, secondary metabolites, folk medicine

\section{INTRODUCTION}

Linnaea borealis L. (eng. twinflower; pol. zimoziół północny, Linnea północna; nor. Nårislegras, Flismegras) belongs to Linnaeaceae family, formerly to Caprifoliaceae $[1,2]$. An updated description of the Linnaea genus was provided by Christenhusz in 2013 [3]. The genus Linnaea was reviewed and expanded to include the genera: Abelia, Dipelta, Diabelia, Kolkwitzia and Vesalea. In general, in the new depiction this taxon consist of 16 species.

\footnotetext{
** This article was written by dr. Elisabeth Buk-Berge under her own responsibility. The opinions expressed in this article are the author's own and do not reflect the point of view of her employer.
} 
L. borealis, a plant with beautiful and delicate flower of native pinewoods, is a relict of Late Glacial period. The twinflower's range includes North $\mathrm{Eu}-$ rope, Asia and a part of North America [4]. In Poland, it reaches the southern extent of its range [5]. In Norway, $L$. borealis is a common species throughout the country $[6,7]$. In Sweden, it is also a common taxon from the region of Smảland in South and northwards [7].

Twinflower's specific name 'borealis' reflects its northern distribution, while the other part of its binomial scientific name honors Carolus Linnaeus, the Swedish botanist who developed the modern system of taxonomic classification. The naming history of this plant is very interesting. Carl Linnaeus described the plant on his journey to Lapland in 1732. Campanula serpyllifolia, as this plant was first called, was renamed as suggested by Jan Frederik Gronovious in honor of Linnaeus who was his close friend $[8,9]$. $L$. borealis was reported to be Linnaeus favorite plant and became Linnaeus' symbol, called 'Herba nostra' (my flower) also depicted in Linnaeus coat of arms.

This paper provides a short review related to botany, distribution, chemical compounds, folk medicinal uses and the role, which twinflower plays in Scandinavian culture.

\section{Botanical description and taxonomy}

L. borealis is a small, creeping, perennial plant (fig. 1). It is an evergreen, stoloniferous dwarf shrub characterized by the above-ground runners. The main stems are slender but woody, elongate, creeping, slightly hairy when young, and often also glandular. Long runners producing numerous short, erect, leafy stems (less than $10 \mathrm{~cm}$ tall). From these stolons grow numerous short lateral shoots. They bear small elliptic or round leaves which are opposite to each other. The shoots are of three different kinds: horizontal shoots, vertical sexually reproductive shoots (the flowering shoots have inflorescences up to $15 \mathrm{~cm}$ tall) and the non-sexually reproductive ones (with only leaves on them). The stolons are first produced when the plant is 5-10 years old, and they grow in annual segments which can be as much as ca. $50 \mathrm{~cm}$ long. The roots are formed along the stolons and are initiated at the nodes of previous year segment. The stolons also produce branches, and when a branch becomes separated from the main stolon, it grows on to form a new plant $[7,10]$. Cytogenetic study of Packer [11] revealed that the number of chromosomes in cells of L. borealis is $2 \mathrm{n}=32$.

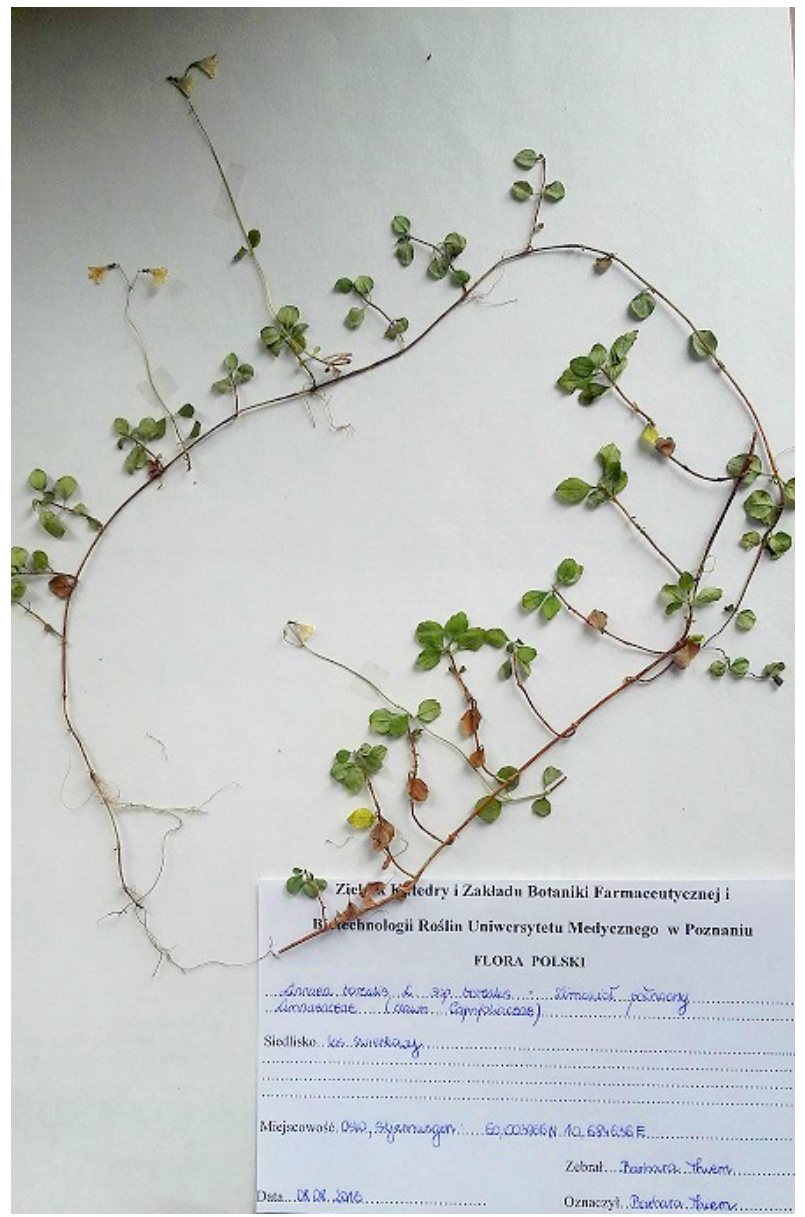

Figure 1.

Linnaea borealis L. from herbarium [fot. B. Thiem]

Twinflower's common name arises from its distinctive and unique inflorescence which is composed of two bell-shaped flowers growing on a forked stem of letter Y shape (fig. 2). The flowers, white or pinkishwhite in color, downward facing and sweetly scented, produce nectar which attracts pollinating insects. Blossom time is typically June or early July in Europe,

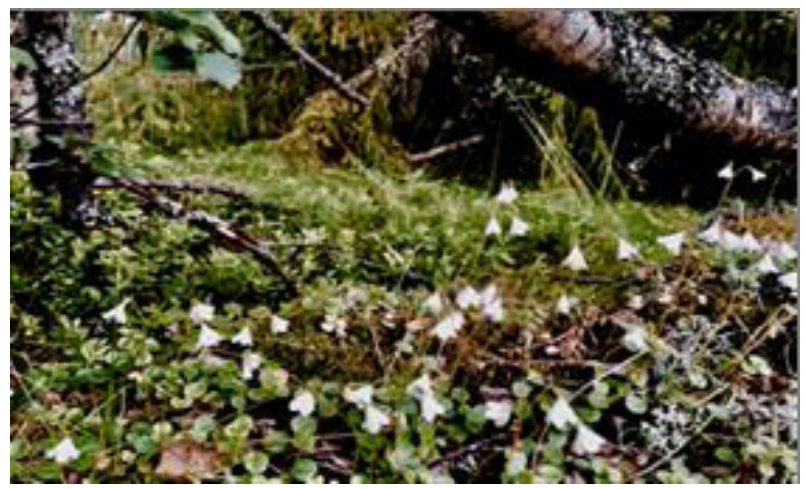

Figure 2.

L. borealis in coniferous forest Skjennungen near Oslo (Norway) [fot. E. Buk-Berge] 
however elsewhere in its range it can flower as late as in September. Individual blossoms persist for about 7 days, and after pollination the flower develops into a fruit in the form of a small, dry, one-seeded capsule, which ripes after 36 days. Twinflower spreads by zoochory - its seeds are dispersed by birds or by small animals, and are partially-covered in small, hairy bracts which stick to the fur of wildlife and are thereby transported to new sites $[4,12]$. Although seed production is plentiful, only a small percentage of seeds has been found viable. Seedlings are rarely observed, mainly growing on disturbed ground. As a shallow-rooted species, twinflower is susceptible to drought. Populations of $L$. borealis are decreasing in some sites due to the loss of its pinewood habitat, so twinflower is a rare plant in several areas. However, in some countries, like in Norway, twinflower is occurring in abundance.

Three subspecies of twinflower are recognized: Linnaea borealis L. ssp. borealis, L. borealis L. ssp. americana (Forbes) Hultén ex R.T. Clausen and L. borealis L. ssp. longiflora (Torr.) Hultén. The latter taxon has two synonyms: L. americana Forbes and L. borealis var. americana (Forbes) Rehder $[12,13]$.

\section{Distribution and habitats}

Twinflower has a circumboreal distribution, occurring from Scotland and northern Europe through Russia to Siberia, northern Asia to Kamchatka and Japan, northern China and Mongolia and from Alaska and Canada to Greenland. Moreover, in the USA it is found as far south as Northern California, New Mexico and West Virginia. The main distribution of twinflower in Europe is in the Nordic countries.

L. borealis ssp. borealis grows in Europe (including Poland), Asia and Alaska. In Grenland and North America, L. borealis ssp. americana is the widespread taxon, occurring throughout the species range, while the longtube twinflower, $L$. borealis ssp. longiflora, has a more restricted distribution in the Pacific Northwest region [13].

Poland marks the southern border of the reach of this species. In Poland, L. borealis occurs in more than 200 localities, concentrated mainly in the northern part of the country and the Lublin region [4]. The highest twinflower site found in Poland is in the West Tatra at the altitude of $1450 \mathrm{~m}[4,14,15]$. Localites of $L$. borealis occurrence are highly nonstable since they are a result of retreating from some sites and the appearance of the another. Twinflower is often described as 'a relict of the wandering' or pseudo-relict [16, 17]. Until recently there have been numerous localites of $L$. borealis in the district of Wolin National Park (WNP) and the abundance of twinflowers populations in Wisełka region described by Piotrowska [18]. At present, these localities disappear gradually, which may be due to habitat changes: altered light conditions (light deficiency) and increase in canopy cover and growth of the shrub layer (processes of succession) [verbal information from WNP 2017]. L. borealis is a characteristic plant of the acidophilic coniferous forests. In Far North, twinflower grows in tundra and taiga, mostly in a light shadow, in a widely spaced tree stands. The species prefers sandy, poor and acidic soil. It doesn't put up with calcium in soil. Often covers tree stumps and moss covered rocks. In general, the populations show strong viability, however, slightly varying. In dry years the size of populations drastically decreases, and it increases during moisty years [4].

The reason for the disappearance of twinflower stands is primarily habitat change associated with forest management and succession. One of the most important environmental factors affecting the L. borealis populations is the light availability $[7,10,19$ 21]. As it was indicated in numerous studies, twinflower grows in the direction of moderate sunlight, but not in full sun. That is why many stations of this species are found near woody roads and tracks. Competitive undergrowth species, such as Vaccinium myrtillus and V. vitis-idaea, limit the twinflower populations. Despite of the fact that twinflower blooms at all of the stations, fruiting specimens rarely occurs in Poland and were found only in a few localities [17].

\section{Propagation}

L. borealis flowers are entomophilous; approached by many different insect species. As mentioned above, twinflower is self-incompatible and requires cross-pollination to produce viable seeds. Fructification is rare due to long distances between clonal patches. Flowers on different plants are to far away one from another to be cross pollinated by insects which are not able to make the distance. As a result, twinflower is rarely propagated by generative methods especially on small isolated sites, where seeds are often not produced or seedling germination does not occur. $L$. borealis plants in a forest stands often intensively spread by stolons to form large 
clonal patches consisting of groups of genetically identical plants. Such clonal patches of twinflower can be long-persisting, which may be hundreds of years old $[7,10,21]$.

Attractive appearance during flowering makes twinflower a popular garden plant. It is used as an ornamental plant, but it is not easy to establish in cultivation. $L$. borealis can be propagated mainly by vegetative and rare by generative methods. In cultivation, generative propagation by seed gives best results when sown as soon as it is ripe in autumn in a cold frame. Seeds require a period of cold stratification. The seedlings have to be pricked out into individual pots and grow in the greenhouse for their first winter. In late spring or early summer, the sprouts may be planted out into their permanent position. Vegetative methods for garden propagation are both division of rooted runners in the spring and cuttings of half-ripe wood in summer [22].

\section{Conservation status in Europe}

Twinflower is generally quite abundant throughout its range, so it is not considered endangered at an international level. However, the situation is different in a few areas. Twinflower has been endangered in Poland, Germany and Slovenia, it is also becoming quite rare in Scotland. Scandinavian countries are different: this species is abundant there [6,7].

In Poland, L. borealis is a rare, protected and designated as endangered species in many regions. This taxon was earlier strictly protected [23], but it has changed and the plant is now under partial protection [24]. In some regions, twinflower is considered to be extinct (category RE), while in others is critically endangered (CR): in the Południowopodlaska Lowland [17], Wielkopolska region [25] and Polish Carpathians $[17,26]$.

\section{Bioactive compounds}

The chemical composition of $L$. borealis herb is described only by few data in Colombia University dissertation on phytochemical study of Caprifoliaceae [27] (fig. 3). Some flavonoids and phenolic acids as secondary metabolites have been reported in ethanolic extracts from leaves of $L$. borealis ssp. longiflora and L. borealis ssp. americana. There are glycosides of quercetin (quercetin 3-O-rhamnoglucoside, quercetin 3-O-glucoside) and kaempferol (kaempferol 3-O-glucoside) as well as apigenin and luteolin derivatives (apigenin 7-O-glucoside, apigenin 7-Orhamnoglucoside and luteolin 7-O-glucoside).

Among phenolic acids, Glennie [27] identified several compounds: $p$-coumaric acid (4-hydroxycinnamic), $p$-hydroxybenzoic acid, caffeic acid (3,4-dihydroxycinnamic), ferulic acid (3-methoxy4-hydroxycinnamic), protocatechuic acid (3,4-dihydrooxybenzoic), vanillic acid (3-methoxy-4-hydroxybenzoic), phloretic acid (4-hydroxydihydrocinnamic) and four chlorogenic acid isomers (3-caffeoylquinic, 4-caffeoylquinic, 3,4-caffeoylquinic, 4,5-caffeoylquinic).

Floral scent is desribed as almond-like or aniselike and consists of four benzoid compounds: 1,4-dimethoxybenzene, anisaldehyde, 2-phenylethanol, and benzaldehyde, and one nitrogen-containing compound, nicotinaldehyde [7].

\section{Folk medicinal and other usages}

In Norwegian folk medicine, $L$. borealis has a long tradition as a cure for shingles (herpes zoster). In the past, this species was also used to treat other kinds of rash, eczema, measles, hives, ringworm, scabies, water blisters, rheumatism and finger infections. Numerous vernacular names reflect this use, e.g.'nårislegras', 'flismegras' [28]. The plant was applied either internally (as a decoction) or externally (as an ointment, in compresses or by exposing the patient to smoke). According to Alm [6], the plant was usually boiled in water, but sometimes in milk or cream and the decoction was usually drunk in the morning, before breakfast. In most cases, it is likely (but not specified) that the whole plant was used. Tea has been prepared from the flowers. The plant has been boiled in beer or extracted with alcohol. It has also been used fresh, simply by placing it around the waist [6].

The use of L. borealis to treat shingles and skin diseases is almost entirely restricted to Norway. In older tradition, twinflower was often used in combination with other remedies, e.g. with a lichen called 'elvenuver' (probably Lobaria pulmonaria /L./ Hoffm.) to smoke the body every evening. The leaves were placed in a dry coffeepot and heated. In Sweden, Finland and Russia, L. borealis is widely known as a remedy for treatment of rheumatism [6]. Similar uses in folk medicine were observed in Scotland, North England and more sporadic in Denmark, Poland, Kaukasus, Grenland [28]. In North America, twinflower was also used in folk medicine. According to Moerman [29] the entire 
<smiles>COc1ccc(OC)cc1</smiles>

1,4-dimethoxybenzene<smiles>O=Cc1ccccc1</smiles>

benzaldehyde<smiles>O=Cc1cccnc1</smiles>

nicotinaldehyde<smiles>COc1ccc(C=O)cc1</smiles>

anisaldehyde<smiles>OCCc1ccccc1</smiles>

2-phenylethanol<smiles>[R]c1cc(C(=O)O)ccc1O</smiles>

$\mathrm{R}=\mathrm{H}-p$-hydroxybenzoic acid $\mathrm{R}=\mathrm{OH}-$ protocatechuic acid $\mathrm{R}=\mathrm{OMe}-$ vanillic acid<smiles>[R6]O[C@H]1C[C@@](O)(C(=O)O)C[C@H]([R6])[C@H]1O[R6]</smiles><smiles>[R]c1cc(/C=C/C(=O)O)ccc1O</smiles>

$\mathrm{R}=\mathrm{H}-p$-coumaric acid $\mathrm{R}=\mathrm{OH}-$ caffeic acid $\mathrm{R}=\mathrm{OMe}-$ ferulic acid<smiles>O=C(O)CCc1ccc(O)cc1</smiles>

p-hydroxyphenylpropionic acid (phloretic acid)

$\mathbf{R}_{1}=\mathbf{R}_{2}=\mathbf{H}, \mathbf{R}_{3}=\mathbf{X}-5$-caffeoylquinic acid

$\mathbf{R}_{1}, \mathbf{R}_{3}=\mathbf{H}, \quad \mathbf{R}_{2}=\mathbf{X}-4$-caffeoylquinic acid

$\mathbf{R}_{1}=\mathbf{H}, \mathbf{R}_{2}=\mathbf{R}_{3}=\mathbf{X}$ - 4,5-dicaffeoylquinic acid

$\mathbf{R}_{\mathbf{1}}=\mathbf{R}_{\mathbf{2}}=\mathbf{X}, \mathbf{R}_{3}=\mathbf{H}$ - 3,4-dicaffeoylquinic acid<smiles>[R]c1c(-c2ccc(O)c(O)c2)oc2cc(O)cc(O)c2c1=O</smiles>

$\mathrm{R}=$ rhamnoglucosyl (quercetin 3-O-rhamnoglucoside) $\mathrm{R}=$ glucosyl (quercetin 3-O-glucoside)<smiles>[R20]Oc1cc(O)c2c(=O)cc(-c3ccc(O)cc3)oc2c1</smiles>

Ram $=$ rhamnosyl apigenin 7-O-rhamnoside<smiles>COc1c(-c2ccc(O)cc2)oc2cc(O)cc(O)c2c1=O</smiles>

Glu = glucosyl kaempferol 3-O-glucoside<smiles>COc1cc(O)c2c(=O)cc(-c3ccc(O)c(O)c3)oc2c1</smiles>

Glu = glucosyl luteolin 7-O-glucoside

\section{Figure 3.}

The chemical structures of components of Linnaea borealis - floral scent compounds, phenolic acids and flawonoids. 
plant of $L$. borealis var. americana was used as a squaw medicine and food plant by the Carrier Indians. Among the white men, the plant has been used as a bitter, a sub-astringent and an antirheumatic. Several Indian tribes used the plant for medicinal purposes as a tonic in pregnancy and also in the treatment of painful or difficult menstruation. A decoction of twigs was given to children with cramps, fever or for crying and a decoction of leaves was taken for colds. The mashed plant was used as a poultice on inflamed limbs and was also applied to ease the headaches [29].

At present, dietary supplement from flowers of L. borealis is obtained as a part of New Essences Research Program carried out by Alaskan Essence Inc. According to the recommendation, this product: Assists the body/mind to more easily take in and integrate sensory stimuli in [the consumer's] surroundings. Calms mental confusion and the sense of being overwhelmed from sensory overload' [30].

As Polish name of twinflower 'zimoziół' indicates, this plant was also used in folk medicine in Poland. Liquid was made for building up the strength in pregnancy or for soothing menstrual complaint, as it was also the case with some Indian tribes mentioned above. Pap of raw plant was used as remedy for painful limbs and headache.

Recently, this species is used in cosmetology. The extract of the whole plant of $L$. borealis is listed in International Nomenclature of Cosmetic Ingredients as cosmetic ingredient and used in cosmetic preparations with skin conditioning properties.

This beautiful plant with delicate flowers is used as an ornamental plant for ground cover in woodland and rock gardens. L. borealis ssp. americana is especially well fitted for gardening as this subspecies forms an extensive twiggy mat and is useful as a ground cover on peat beds. However, plants can be rather difficult to establish. They require an acid soil and prefers a shaded position in a moist peaty soil. The subspecies $L$. borealis ssp. americana grows more freely than the European form.

\section{Linnaea borealis in Scandinavian culture}

Twinflower is one of the favorite decorative plant motifs in Sweden that can be found on postcards, tableware and tableclothes, and in painting (fig. 4, 5). Twinflower is also a plant symbol of Smaland, the region in Sweden, where Linnaeus comes from. Not surprising, this little plant is often depicted on portraits of this great botanist. From 2015, twinflower is to be found on Swedish twenty-crowns note (back side). L. borealis is also used as a motif on postcards and post stamps in Sweden, Finland and USA. For many people the word 'Linnaea' is mostly associated with female names 'Linnèa' or 'Linnea', which are very common in Sweden and Norway.

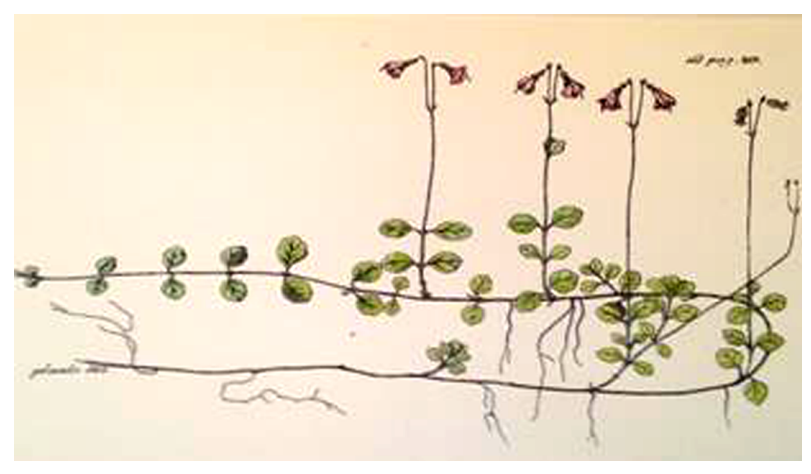

Figure 4.

L. borealis postcard with illustration from Carl Linnaeus „Flora Svecica”

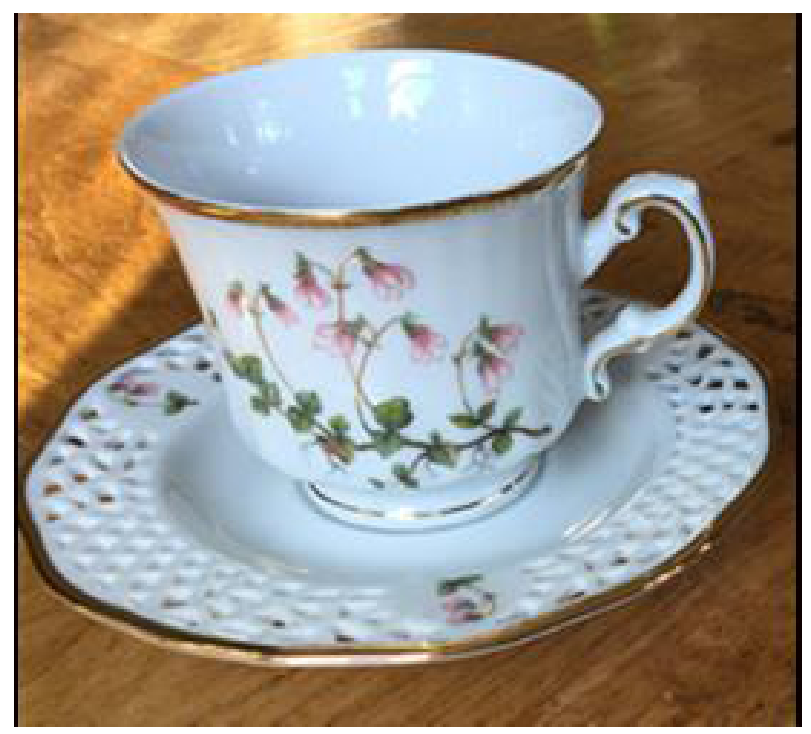

Figure 5.

L. borealis as a decorative motif on tableware [fot. E. Buk-Berge]

\section{CONCLUSIONS}

Traditional medicinal use of $L$. borealis needs further scientific exploration. Ethnobotanical data, mainly from Norway, indicate that $L$. borealis may have potential health promoting activity. Due to high demand for herbal products for treatment of skin disease, new phytochemical and pharmaceutical investigation of twinflower is needed for confirmation of their potential biological and 
medicinal properties. Local knowledge of L. borealis used by the people of South Norway and North America for medicinal and food purposes seems to be well known to its culture and tradition. The evidence on chemical composition of twinflowers, from only two American subspecies, is very scarce and based on data from 1969. L. borealis ssp. borealis could have different chemical profile and new studies on lead secondary metabolites responsible for potential medicinal activity are necessary. Phytochemical investigation of European subspecies (from Norway) is currently carried out in Department of Pharmaceutical Botany and Plant Biotechnology of Poznań University of Medical Sciences (Poland).

\section{REFERENCES}

1. Backlund A, Pyck N. Diervillaceae and Linnaeaceae, two new families of caprifolioids. Taxon 1998; 47(3):657-661. doi: http://dx.doi. org/10.2307/1223583

2. Mirek Z, Piękoś-Mirkowa H, Zając A, Zając M. Flowering plants and pteridophytes of Poland. A checklist. Kraków. W. Szafer Institute of Botany, Polish Academy of Sciences 2002:103.

3. Christenhusz MJM. Twins are not alone: a recircumscription of Linnaea (Caprifoliaceae). Phytotaxa 2013; 125(1):25-32. doi: http://dx.doi. org/10.11646/phytotaxa.125.1.4

4. Piękoś-Mirkowa H, Mirek Z. Flora Polski. Atlas roślin chronionych. Warszawa 2003:92-93.

5. Zając A, Zając M, eds. Atlas rozmieszczenia roślin naczyniowych w Polsce. Pracownia Chorologii Komputerowej Instytutu Botaniki Uniwersytetu Jagiellońskiego, Kraków 2001:334.

6. Alm T. Ethnobotany of Linnaea borealis (Linnaeaceae) in Norway. Bot J Linn Soc 2006; 151: 437-452. doi: http://dx.doi.org/10.1111/j.10958339.2006.00516.x

7. Niva M. Life history strategies in Linnaea borealis. Acta Univ Upsal, Comprehensive Summaries of Uppsala Dissertations from the Faculty of Science and Technology 2003; 893:1-21.

8. Zemanek A, Pawłowski J. Karol Linneusz (1707-1778) w trzechsetną rocznicę narodzin.
Prace Komisji Historii Nauki PAU 2010; 10:205209.

9. Frey L. Karol Linneusz. Książę Botaników, Profesor Profesorów. Instytut Botaniki im. W. Szafera PAN, Kraków 2010:70-73.

10. Niva M, Svensson BM, Karlsson PS. Effects of light and water availability on shoot dynamics of the stoloniferous plant Linnaea borealis. Ecosci 2006; 13(3):318-323. doi: http://dx.doi. org/10.2980/i1195-6860-13-3-318.1

11. Packer JG. Chromosome numbers and taxonomic notes on western Canadian and Arctic plants. Can J Bot 1964; 42:473-494. doi: http://dx.doi. org./10.1139/b64-047

12. Trees for Life. Twinflower. http://treesforlife.org. uk/forest/species-profiles/twinflower/ (accessed 11.09.2017)

13. USDA Plants Database, https//plants.usda.gov/ (accessed 11.09.2017)

14. Zarzycki K. Rodzina: Caprifoliaceae, Przewiertniowate. In: Pawłowski B, ed. Flora Polska. Rośliny naczyniowe Polski i ziem ościennych. Tom XI. Warszawa-Kraków 1967:324-337.

15. Puchałka R, Czarnowska J, Czarnowski G, Rutkowski L. Nowe stanowisko zimoziołu północnego Linnaea borealis (Caprifoliaceae) koło Torunia. Chrońmy Przyr Ojcz 2015; 71(2): 157-160.

16. Wolańska-Kamińska A, Zając I, Ratajczyk N. Efekty ochrony rzadkich gatunków roślin na przykładzie zimoziołu północnego Linnaea borealis w rezerwacie Górki. Sylwan 2014; 158(7):531538.

17. Ciosek MT, Krechowski J, Sikorski R, Trębicka A, Piórek K. The twinflower (Linnaea borealis L.) in the northern part of the Południowopodlaska Lowland. Leśne Prace Badawcze 2015; 76(2):113121. doi: http://dx.doi.org/10.1515/frp-2015-0011

18. Piotrowska H. Rośliny naczyniowe wysp Wolina i południowo-wschodniego Uznamu. PTPN, Wydz. Mat-Przyr, Prace Kom Biol 1966; 30(4):1282

19. Zawadzka D, Zawadzki G, Bednarek J, Bednarek JB, Piechowska D, Mikitiuk A. Występowanie, 
kondycja i zagrożenia zimoziołu północnego w Puszczy Augustowskiej. Leśne Prace Badawcze 2017; 78(1):77-87. doi: http://dx.doi.org/10.1515/ frp-2017-0008

20. Browicz K, Gostyńska-Jakuszewska M. Linnaea borealis L. In: Białobok S, Czubiński Z, eds. Atlas rozmieszczenia drzew i krzewów w Polsce. Tom 5. PAN, Zakład Dendrologii i Arboretum Kórnickie, Warszawa 1966:21-24.

21. Scobie AR, Wilcock CC. Limited mate availability decreases reproductive success of fragmented populations of Linnaea borealis, a rare clonal self-incompatible plant. Ann Bot 2009; 103(6):835-846. doi: http://dx.doi.org/10.1093/ aob/mcp007

22. Eriksson O. Variation in growth rate in shoot populations of the clonal dwarf shrub Linnaea borealis. Holarctic Ecol 1988; 11(4):259-266. doi: http://dx.doi.org/10.1111/j.1600-0587.1988. tb00808.x

23. Rozporządzenie Ministra Środowiska $\mathrm{z}$ dnia 5 stycznia 2012 r. w sprawie ochrony gatunkowej roślin. Dz.U.2012 nr 0 poz.81.
24. Rozporządzenie Ministra Środowiska z dnia 9 października 2014 r. w sprawie ochrony gatunkowej roślin Dz.U.z 2014 r. Nr 0, poz.1409.

25. Jackowiak B, Celka Z, Chmiel J, Latowski K, Żukowski W. Red list of vascular flora of Wielkopolska (Poland). Biodiv Res Conserv 2007; 5-8:95-127.

26. Piękoś-Mirkowa H. Zimoziół (Linnaea) północny. In: Mirek Z, Piękoś-Mirkowa H, eds. Czerwona Księga Karpat Polskich. Rośliny naczyniowe. Instytut Botaniki im. W. Szafera PAN, Kraków 2008: 294-295.

27. Glennie WCh. Comparative phytochemical study of Caprifoliaceae. UBC Thesis and Dissertation, The University of British Columbia, 1969:3-96.

28. Brondegaard VJ. Linnaea i folkemedicine. Svenska Linnésällskapets Arsskrift 1959; 42:89-98.

29. Moerman DE. Native American Ethnobotany. Portland OR, Timber Press 1998

30. http://alaskanessences.com/pages (accessed 23.06.2017)

\title{
Zimoziół północny (Linnaea borealis L.) - gatunek rośliny o potencjalnych właściwościach leczniczych
}

\author{
BARBARA THIEM ${ }^{1 *}$, ELISABETH BUK-BERGE ${ }^{2}$
}

\author{
${ }^{1}$ Katedra i Zakład Botaniki Farmaceutycznej i Biotechnologii Roślin \\ Uniwersytet Medyczny im. Karola Marcinkowskiego w Poznaniu \\ ul. Św. Marii Magdaleny 14 \\ 61-861 Poznań \\ ${ }^{2}$ The Norwegian Ministry of Education and Research \\ Postbox 8119 \\ Dep. 0032 Oslo, Norway \\ *autor, do którego należy kierować korespondencję: tel.: +48 61668 7851, faks: +48 616687861 , \\ e-mail: bthiem@ump.edu.pl
}




\section{Streszczenie}

Zimoziół północny (Linnaea borealis L.) jest szeroko rozpowszechnionym gatunkiem cyrkumborealnym, należącym do rodziny Linnaeaceae (wcześniej Caprifoliaceae). Licznie rośnie w tajdze i tundrze. W kilku krajach Europy, także w Polsce, zimoziół został objęty ochroną gatunkową jako relikt glacjalny. W medycynie ludowej krajów skandynawskich $L$. borealis cieszy się długą tradycją stosowania w chorobach skórnych i reumatycznych, co wskazuje na potencjalne właściwości lecznicze omawianego gatunku. Jego profil chemiczny jest słabo poznany, dlatego wskazane są nowe badania głównych metabolitów wtórnych, które mogą być odpowiedzialne za aktywność biologiczną surowca. Niniejszy artykuł stanowi krótki przegląd dostępnej literatury, podsumowując skromną wiedzę na temat $L$. borealis z zakresu biologii, występowania, ochrony gatunku, obecności związków czynnych, stosowania w medycynie tradycyjnej i miejsca tego gatunku w kulturze krajów skandynawskich.

Słowa kluczowe: Linnaea borealis, opis botaniczny, rozmieszczenie, wtórne metabolity, medycyna ludowa 